\title{
Advances in the diagnosis and treatment of sarcoidosis
}

\author{
Marc A. Judson
}

Address: Division of Pulmonary and Critical Care Medicine MC-91, Albany Medical College, Albany, New York 12208, USA

Email: judsonm@mail.amc.edu

Fl000Prime Reports 2014, 6:89 (doi:10.12703/P6-89)

All F1000Prime Reports articles are distributed under the terms of the Creative Commons Attribution-Non Commercial License (http://creativecommons.org/licenses/by-nc/3.0/legalcode), which permits non-commercial use, distribution, and reproduction in any medium, provided the original work is properly cited.

The electronic version of this article is the complete one and can be found at:http://f 1000 .com/prime/reports/m/6/89

\begin{abstract}
This manuscript outlines recent advances in the diagnosis and treatment of sarcoidosis. The diagnosis of sarcoidosis can occasionally be made on clinical grounds without a confirmatory biopsy when very specific clinical findings are present. Otherwise, the diagnosis requires histologic evidence of granulomatous inflammation, exclusion of alternative causes, and evidence of systemic disease. Because there is no available diagnostic test for sarcoidosis, the diagnosis is never completely secure. Instruments have been developed to establish the presence of sarcoidosis in a second organ and hence establish the systemic nature of the disease. Corticosteroids remain the drug of choice for the treatment of sarcoidosis. Additional sarcoidosis medications are most commonly used as corticosteroid-sparing agents. Recent clinical sarcoidosis drug trials have exposed important issues that may confound trial results, including selecting patients with active disease, identifying study drug effects in patients receiving concomitant corticosteroids, and establishing proper study endpoints.
\end{abstract}

\section{Introduction}

Although sarcoidosis has been identified as a specific disease entity for more than one century [1], the specific cause of sarcoidosis is unknown. In addition, the diagnostic criteria, treatment algorithms, method of follow-up and natural course of the disease have not been clearly elucidated. This manuscript will review evolving concepts concerning the diagnosis and treatment of sarcoidosis. These concepts reflect our deeper understanding of this enigmatic disease.

In terms of the diagnosis of sarcoidosis, presently, this is a clinical diagnosis as there is no reliable diagnostic test. In lieu of a diagnostic test, diagnostic criteria have been developed. These criteria will be outlined in this manuscript. Although these diagnostic criteria are based on clinical data and have been vetted by world experts in the field, they are arbitrary and inexact. These issues will also be discussed.

In terms of the treatment of sarcoidosis, the indications for treatment and the optimal treatment approach have not been standardized. There is a general consensus that corticosteroids are the drug of choice when treatment is required. Several alternative agents may be used, usually as corticosteroid sparing agents, because of the development of significant corticosteroid toxicity. The assessment of the efficacy of alternative anti-sarcoidosis medications is complex for many reasons, including distinguishing the effects of corticosteroids from the study drug and reliably assessing disease activity.

\section{Advances in the diagnosis of sarcoidosis}

Presently, there is no specific diagnostic test for sarcoidosis. The diagnosis of sarcoidosis is never secure but is arbitrarily made when the statistical likelihood of alternative diagnoses becomes too small to warrant further investigation [2]. Figure 1 depicts the current diagnostic algorithm for sarcoidosis. On occasion, a patient may present with a constellation of clinical findings that is so specific for sarcoidosis that the diagnosis may be made empirically without the need for a confirmatory biopsy (left side of Figure 1). If these rare presentations are not observed, the diagnosis requires a tissue biopsy revealing granulomatous inflammation (usually noncaseating), exclusion of alternative causes of granulomatous inflammation, and documentation of systemic disease (right side of Figure 1).

This diagnostic algorithm implies several subtleties. First, granulomatous inflammation is, by itself, inadequate to 
Figure I. The diagnostic algorithm for sarcoidosis

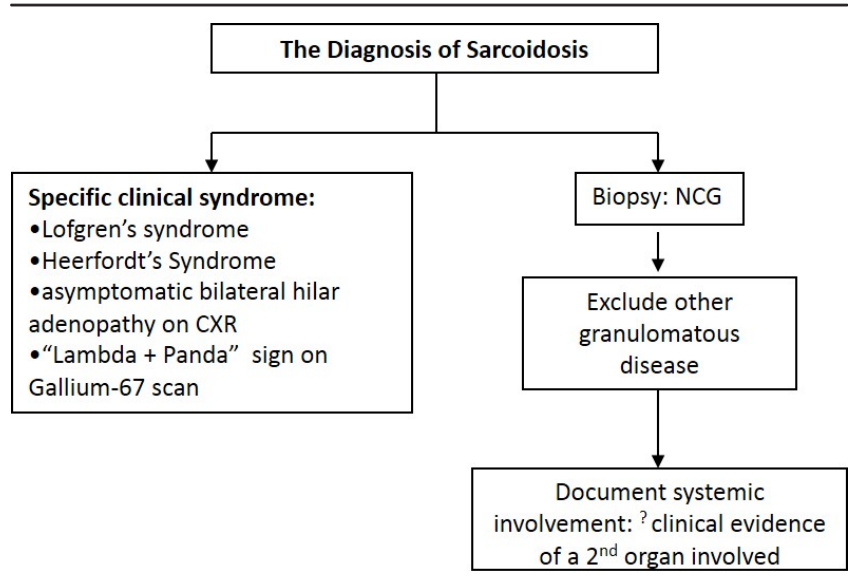

The diagnosis of sarcoidosis may be established without performing a tissue biopsy (left side of figure). This requires the presence of specific clinical findings that are highly specific for the diagnosis (one of the conditions in the box on the left side of the figure). If none of these specific clinical presentations occurs, then the diagnosis requires tissue biopsy confirmation of granulomatous inflammation, exclusion of alternative causes for the granulomatous inflammation, and documentation that the disease is systemic and is, therefore, not confined to a single organ (pathway on the right side of the figure). Abbreviations: CXR, chest radiograph; NCG, noncaseating granulomas; ?, controversial criterion.

establish a diagnosis of sarcoidosis. In one recent study of 131 lung biopsy specimens revealing necrotic granulomatous lesions without an obvious etiology, 52 (40\%) remained unknown, and only 4/79 (5\%) of those where the etiology was determined were found to have sarcoidosis [3].

Second, the diagnosis of sarcoidosis requires that alternative causes of granulomatous inflammation are excluded. Table 1 lists potential alternative causes of granulomatous inflammation. Although biopsy specimens are usually examined for the presence of mycobacteria and fungi, other alternative granulomatous diseases are more problematic to exclude. Chronic beryllium disease may completely mimic sarcoidosis both histologically $[4,5]$ and radiographically [6]. In one German sarcoidosis clinic, patients diagnosed with sarcoidosis completed a detailed questionnaire concerning occupations where exposure to beryllium was possible. Over 7 years, 84 patients had posi-tive responses to this questionnaire, and $34 / 84(40 \%)$ of these patients were confirmed to have chronic beryllium disease, rather than sarcoidosis, on the basis of beryllium lymphocyte proliferation testing [7].

Third, sarcoidosis is a systemic disease that is not confined to the lung or any organ in isolation. Some features that show sarcoidosis is a systemic illness are that the disease is associated with anergy [8], non-granulomatous inflammatory conditions such as erythema nodosum [9], systemic symptoms such as fatigue [10] and small fiber neuropathy $[11,12]$, and that the disease may recur in transplanted allografts [13]. Usually, confirmation that the disease is systemic involves identifying granulomatous inflammation in at least two organs. Indeed, idiopathic granulomatous diseases of some isolated organs are thought to be distinct from sarcoidosis, such as idiopathic granulomatous hepatitis [14]. More than one decade ago, the National Institute of Health sponsored A Case Control Etiologic Study of Sarcoidosis (ACCESS) that developed an organ assessment instrument to document a second organ being involved with sarcoidosis, short of performing a biopsy [15]. The instrument classified the likelihood of several specific clinical scenarios being caused by sarcoidosis in an organ as "definite", "probable", or "possible" provided that a) granulomatous inflammation had already been identified in another organ, and b) alternative causes for the clinical scenario could reliably be excluded. For example, if histologic evidence of granulomatous inflammation was found on skin biopsy, then eye sarcoidosis was considered "definite" if the patient had uveitis of no other likely cause. For the purposes of ACCESS, definite or probable involvement was considered as sarcoidosis involvement in that organ. Therefore, the ACCESS instrument allowed for the diagnosis of sarcoidosis to be established by confirming the presence of sarcoidosis in a second organ, without the need to biopsy that second organ. More recently, the World Association of Sarcoidosis and Other Granulomatous Disorders (WASOG) has updated the ACCESS assessment instrument to take into account new advances in diagnostic technology [16].

However, an issue that has recently surfaced is whether the requirement of documenting involvement of a second organ/systemic disease is universally required for the diagnosis of sarcoidosis [17]. Despite the aforementioned idiopathic granulomatous diseases in single organs that appear to be distinct from sarcoidosis, there may be specific presentations in single organs that are highly specific for sarcoidosis. Two such examples would be lupus pernio (disfiguring facial sarcoidosis) and chest imaging, revealing mediastinal adenopathy plus parenchymal lung nodules in a perilymphatic distribution [18]. If granulomatous inflammation was identified in such clinical situations and no other evidence of granulomatous inflammation was identified in other organs, most would consider the diagnosis of sarcoidosis secure. Indeed, most large sarcoidosis series reported by sarcoidosis experts, including the multicenter ACCESS trial investigators, have reported a large proportion of patients as having sarcoidosis with only a single organ involved (366/736, 49.7\%) [19]. As a counter-argument to this viewpoint, a recent 
Table I. Major pathologic Differential Diagnosis of Sarcoidosis at Biopsy

\begin{tabular}{|c|c|c|c|c|c|}
\hline LUNG & LYMPH NODE & SKIN & LIVER & BONE MARROW & $\begin{array}{l}\text { OTHER BIOPSY } \\
\text { SITES }\end{array}$ \\
\hline $\begin{array}{l}\text { - Tuberculosis } \\
\text { - Atypical mycobacteriosis } \\
\text { - Fungi } \\
\text { - Pneumocystis carinii } \\
\text { - Mycoplasma } \\
\text { - Hypersensitivity } \\
\text { pneumonitis } \\
\text { - Pneumoconiosis: } \\
\text { Beryllium (chronic } \\
\text { beryllium disease), } \\
\text { Titanium, Aluminum } \\
\text { - Drug reactions } \\
\text { - Aspiration of foreign } \\
\text { materials } \\
\text { - Wegener's granulomatosis } \\
\text { (Sarcoid-type granulomas } \\
\text { are rare) } \\
\text { - Necrotizing sarcoid } \\
\text { granulomatosis (NSG) }\end{array}$ & $\begin{array}{l}\text { - Tuberculosis } \\
\text { - Atypical } \\
\text { mycobacteriosis } \\
\text { - Brucellosis } \\
\text { - Toxoplasmosis } \\
\text { - Granulomatous } \\
\text { histiocytic necrotizing } \\
\text { lymphademitis } \\
\text { (Kikuchi's disease) } \\
\text { - Cat-scratch disease } \\
\text { - Sarcoid reaction in } \\
\text { regional lymph nodes } \\
\text { to carcinoma } \\
\text { - Hodgkin's disease } \\
\text { - Non-Hodgkin's } \\
\text { lymphomas } \\
\text { - Granulomatous } \\
\text { lesions of unknown } \\
\text { significance (the } \\
\text { GLUS syndrome) }\end{array}$ & $\begin{array}{l}\text { - Tuberculosis } \\
\text { - Atypical } \\
\text { mycobacteriosis } \\
\text { - Fungi } \\
\text { - Reaction to foreign } \\
\text { bodies: beryllium, } \\
\text { zirconium, tattooing, } \\
\text { paraffin, etc. } \\
\text { - Rheumatoid nodules }\end{array}$ & $\begin{array}{l}\text { - Tuberculosis } \\
\text { - Brucellosis } \\
\text { - Schistosomiasis } \\
\text { - Primary biliary } \\
\text { cirrhosis } \\
\text { - Crohn's disease } \\
\text { - Hodgkin's disease } \\
\text { - Non-Hodgkin's } \\
\text { lymphomas } \\
\text { - GLUS syndrome }\end{array}$ & $\begin{array}{l}\text { - Tuberculosis } \\
\text { - Histoplasmosis } \\
\text { - Infectious } \\
\text { mononucleosis } \\
\text { - Cytomegalovirus } \\
\text { - Hodgkin's disease } \\
\text { - Non-Hodgkin's } \\
\text { lymphomas } \\
\text { - Drugs } \\
\text { - GLUS syndrome }\end{array}$ & $\begin{array}{l}\text { - Tuberculosis } \\
\text { - Brucellosis } \\
\text { - Other infections } \\
\text { - Crohn's disease } \\
\text { - Giant cell myocarditis } \\
\text { - GLUS syndrome }\end{array}$ \\
\hline
\end{tabular}

Adapted from reference [27] and reprinted with permission of the American Thoracic Society. Copyright (C) 2014 American Thoracic Society. Official Journal of the American Thoracic Society.

retrospective analysis of patients with concomitant sarcoidosis and connective tissue diseases (CTDs) suggested that a significant proportion of them may have had solely a CTD, and that the granulomatous inflammation may have been a result of the CTD [20]. Many of these patients had a local granulomatous inflammation in only one organ. Since CTDs are not recognized as a cause of granulomatous inflammation, several of these patients may have been misdiagnosed as having sarcoidosis. Summing up these data, we believe that sarcoidosis can be diagnosed when a single organ is involved, provided that alternative causes have been excluded and the presentation is highly specific for the diagnosis. We do believe that confirming granulomatous inflammation in a second organ does raise the specificity of the diagnosis, albeit with a potential drop in sensitivity.

The entire diagnosis discussion to this point has focused on a set of criteria that are arbitrary. These criteria require that the patient has a clinical presentation suggestive of sarcoidosis and that alternative causes of granulomatous inflammation are reasonably excluded. These are not objective, rigorous conditions. Obviously, sarcoidosis must have a specific cause or causes associated with specific immune mechanisms. Recently, Chen and colleagues demonstrated intense expression and wide distribution of serum amyloid A (SAA) within the sarcoidosis granuloma that exceeded that found in all other granulomatous diseases that were examined [21]. SAA appeared to have been produced by macrophages and giant cells within the sarcoid granuloma. These authors postulated that SAA could consolidate a poorly soluble protein aggregate to form a nidus for granuloma formation. SAA may disrupt the clearance of an antigen within the granuloma that allows for its persistence. The granulomatous inflammation in sarcoidosis may result from a prolonged immunogenic response to a persistent antigen, resulting in immune system exhaustion. As the identification of SAA may be a specific marker for sarcoidosis-related granulomatous inflammation, it may be a reliable diagnostic test for the disease. Hopefully, SAA or another specific biomarker to be developed in the future will make the previous discussion of diagnosis obsolete. Furthermore, such a biomarker may answer the question as to whether several other granulomatous diseases of unknown cause such as Blau's syndrome [22], granulomatous lesions of unknown significance (GLUS Syndrome) [23], granulomatous-lymphocytic interstitial lung disease [24], and necrotizing sarcoid granulomatosis [25], are truly distinct entities from sarcoidosis or whether they fall under the "sarcoidoses umbrella".

\section{Advances in the treatment of sarcoidosis}

Sarcoidosis does not mandate treatment because the disease may never cause symptoms or organ dysfunction, may remit spontaneously [26], and therapy (particularly corticosteroids) is associated with a myriad of significant side effects. Sarcoid granulomas are thought to result from the interaction of an antigen with the immune system [27]. It has been conjectured that granulomatous inflammation in sarcoidosis is necessary to clear the antigen [21]. If this theory is correct, it is plausible that effective anti-sarcoidosis therapy may resolve granulomatous inflammation that 
may result in failure of clearance of the putative sarcoidosis antigen(s). In this scenario, when treatment is withdrawn, the antigen may still be present and could lead to recurrent granulomatous inflammation and, therefore, relapse [28]. This schema is supported by data that suggest that a relapse of sarcoidosis is more common in patients previously treated for sarcoidosis [29], or with higher doses of corticosteroids [30]. In addition, this concept is consistent with the premise that anti-sarcoidosis treatment improves granulomatous inflammation but does not alter the natural course of the disease [21,31-36]. Therefore, the granulomatous inflammation of sarcoidosis may be beneficial and should probably be left unsuppressed, provided that it does not result in significant patient symptoms or organ dysfunction.

When treatment is indicated for sarcoidosis, corticosteroids are considered the drug of choice because they appear to have the greatest likelihood of efficacy and work most rapidly [37]. Although a consensus statement of the American Thoracic Society, European Respiratory Society, and WASOG have recommended 20 to $40 \mathrm{mg}$ of daily prednisone equivalent for the initial treatment of pulmonary sarcoidosis [27], the lower end of that dosage range appears to be adequately effective. A recent review of acute pulmonary exacerbations of sarcoidosis found that $20 \mathrm{mg}$ of daily prednisone for a median of 3 weeks returned spirometry and pulmonary symptoms back to baseline [38]. Indeed, a regimen of $15 \mathrm{mg} /$ day of prednisone was shown to be effective for sarcoidosis more than 40 years ago [32]. Little is known concerning the optimal algorithm for tapering corticosteroids, although relapses with such tapers occur in a significant percent of cases $[28,39]$.

Although corticosteroids are currently entrenched as the drug of choice for most forms of sarcoidosis, alternative agents are often used because of the frequency of the development of corticosteroid side effects. Usually, these drugs are corticosteroid-sparing as often a small amount of corticosteroid must be continued for adequate efficacy $[40,41]$. These corticosteroid-sparing drugs should be considered for patients deemed at risk of developing corticosteroid side effects and most patients who require long-term corticosteroid therapy.

A recent Delphi study of 36 sarcoidosis experts reached a consensus that methotrexate be considered the secondline agent for pulmonary sarcoidosis [37]. In an unusual study design, two European medical centers were compared where one used methotrexate as a second-line antisarcoidosis agent and the other used azathioprine [42]. The reduction in corticosteroid dose and improvement of pulmonary function was not statistically different between these two groups. However, the rate of drug side effects, particularly the rate of infection, was significantly greater in the patients receiving azathioprine as a second-line agent. Leflunomide has also been shown to be an effective anti-sarcoidosis medication in a large number of sarcoidosis patients in the United States [43]. We believe that the use of second-line agents should be individualized based on the patient's potential for toxicity and the organ that is being treated. In regards to this latter point, antimalarial agents are particularly effective for skin sarcoidosis as well as for sarcoidosis-induced derangement of vitamin D metabolism causing hypercalcemia, hypercalciuria, nephrolithiasis and renal insufficiency [44,45]. As these drugs have been shown to be better tolerated than other treatments in rheumatoid arthritis [46], they may be preferred for the aforementioned forms of sarcoidosis.

Over the past decade, several studies have shown a benefit of tumor necrosis factor alpha (TNF- $\alpha$ ) antagonists for the treatment of sarcoidosis. These studies have included case series [47-50] and a randomized double-blind placebocontrolled trial $[51,52]$. There is a sound rationale for this therapy because TNF- $\alpha$ is released by macrophages recovered from sarcoidosis patients [53] and TNF- $\alpha$ is thought to be integrally involved in the development of the granulomatous inflammation $[2,54]$.

Infliximab appears to be a particularly effective for lupus pernio (disfiguring facial sarcoidosis) [49], neurosarcoidosis [50], and pulmonary sarcoidosis [51]. Other TNF- $\alpha$ agents may be less effective. Etanercept was not demonstrated to be of benefit for ocular sarcoidosis [55]. Adalimumab may be effective for sarcoidosis [56,57] although, extrapolating from clinical reports, the optimal dose may need to be higher than that routinely used in rheumatoid arthritis [58]. A recently completed placebocontrolled trial of golimumab failed to show a benefit over placebo for the treatment of pulmonary and cutaneous sarcoidosis. Furthermore, all TNF- $\alpha$ antagonist agents have been occasionally associated with relapse, worsening, or development of sarcoidosis [59-63]. These occurrences are most commonly reported with etanercept and are postulated to be the result of TNF- $\alpha$ antagonist-induced stimulation of interferon-gamma production leading to granulomatous inflammation [59].

One goal of medical care in the future is to develop "personalized" or "precision" medical care where therapy is individualized based on the patient's specific clinical features or genetics [64]. One example of such care is the observation that the presence of the TNF- $\alpha$ G-308A polymorphism in rheumatoid arthritis patients 
is associated with a more favorable response to TNF- $\alpha$ antagonist therapy than those who do not possess this polymorphism $[65,66]$. Recently, these results have been duplicated in a sarcoidosis cohort who received infliximab or adalimumab [67].

Rituximab is a monoclonal antibody directed at the C20 cell surface antigen of B-lymphocytes. Although the granulomatous inflammation of sarcoidosis is thought to primarily develop through an interaction with T-lymphocytes, there is often abnormal B-lymphocyte activity, as demonstrated by the frequent development of a polyclonal gammopathy in active sarcoidosis [68]. Several case reports and open-label case series have shown the potential efficacy of rituximab in the treatment of sarcoidosis [69-72].

The results of recent sarcoidosis drugs trials have uncovered several issues that may be of critical importance in designing future studies. First, subjects with severe forms of sarcoidosis may have a greater potential to respond to therapeutic agents than those with mild disease. A post-hoc analysis of a randomized placebocontrolled trial of infliximab versus placebo for pulmonary sarcoidosis demonstrated the greatest improvement in percent predicted forced vital capacity (FVC) at 24 weeks in those with lower baseline FVC, St. George Respiratory Questionnaire total score, and worse pulmonary symptoms [51]. Although this finding could be explained by a "ceiling effect" where those with mild disease have less room to show significant improvement, it is also possible that those with more severe disease have more severe active granulomatous inflammation. Although it has previously been thought that pulmonary sarcoidosis patients with fibrocystic disease may have "burnt-out" inactive disease, a recent study demonstrated that $85 \%$ of such patients have significant lung uptake on positron emission tomography (PET), suggesting that they have active disease [73]. Because sarcoidosis may result in both treatable granulomatous inflammation and irreversible fibrosis, it is imperative to identify subjects with active disease in clinical sarcoidosis trials. This will require the establishment of reliable biomarkers of active granulomatous inflammation that can be used to select appropriate patients.

A second issue of importance in many sarcoidosis trials is distinguishing study drug effects from corticosteroid effects. Corticosteroids are beneficial for an overwhelming majority of sarcoidosis patients [74]. Alternative agents are still in great demand because of the numerous significant toxicities of corticosteroids. Most clinical trials of potential sarcoidosis patients enroll subjects who are corticosteroid-dependent, as these are the patients who would be potential candidates for these drugs and it would be problematic to taper them off corticosteroids and risk disease exacerbation. Because of the efficacy of corticosteroids, it is problematic to detect additional benefits of the study drug in such patients. As an example of this issue, in a randomized placebo-controlled trial of infliximab versus placebo for pulmonary sarcoidosis, although the trial was positive, those receiving more than $15 \mathrm{mg} /$ day of daily prednisone equivalent did not demonstrate an appreciable additional benefit from infliximab [75]. Potential trial designs to circumvent this issue include a) non-inferiority comparison trials versus corticosteroids in de novo sarcoidosis patients with corticosteroid rescue for study drug failure; b) including a corticosteroid withdrawal phase in the trial; and c) initiating a corticosteroid taper prior to trial enrollment and only enrolling subjects who deteriorate.

Probably the single most challenging issue in the design of a clinical sarcoidosis trial is the establishment of an appropriate endpoint. Figure 2 outlines the issue. The presence of disease activity would be an adequate endpoint for a uniformly progressive disease such as lung cancer or tuberculosis. However, patients with active sarcoidosis may never develop symptoms or pulmonary dysfunction. As previously mentioned, the presence of disease activity should probably be an entry criterion for sarcoidosis clinical trials. In addition, measurement of disease activity may be an appropriate endpoint to detect anti-sarcoidosis activity of a drug. However, reduction of disease activity is an unreliable endpoint to determine if a drug is useful for the treatment of sarcoidosis. Disease activity may progress to cause physiological impairment. However, such impairment is usually mild in sarcoidosis [76] and poorly correlates with impaired quality of life $[77,78]$, which is what patients usually care about most, so this is an appropriate clinical endpoint for most sarcoidosis trials. However, pulmonary symptoms and impaired quality of life are often not directly related to sarcoidosis, so this endpoint is not uniformly reliable. Because this issue is complex and unresolved, some have advocated the use of composite endpoints in sarcoidosis clinical trials [79].

\section{Conclusion}

The diagnosis of sarcoidosis remains a challenging issue principally because there is no specific reliable diagnostic test available. Various algorithms and criteria have been established as diagnostic guidelines that may be useful while we remain hopeful for the development of a gold standard diagnostic test. Clinical treatment trials of novel agents for sarcoidosis will continue. Such trials involve overcoming several problematic issues, but this can be accomplished with prudent thought and planning. 
Figure 2. Potential endpoints for the treatment of sarcoidosis

\begin{tabular}{|c|c|c|c|}
\hline & $\begin{array}{c}\text { Granulomatous } \\
\text { Activity }\end{array}$ & $\begin{array}{l}\text { Physiologic } \\
\text { Impact }\end{array}$ & $\begin{array}{l}\text { Functional } \\
\text { Impact }\end{array}$ \\
\hline & $\begin{array}{c}\text { Development of granulomas, } \\
\text { mediators }\end{array}$ & Derangement of physiology & $\begin{array}{c}\text { Functional impairment, } \\
\text { symptoms }\end{array}$ \\
\hline Measurements: & $\begin{array}{l}\text { - Radiographic imaging } \\
\text { - Nuclear/PET/MRI imaging } \\
\text { - BAL cell counts (lung) } \\
\text { - Serum ACE }\end{array}$ & $\begin{array}{l}\text { - PFT (lung) } \\
\text { - EF, arrhythmias (heart) } \\
\text { - renal function (kidney, } \\
\text { vitamin D dysregulation) }\end{array}$ & $\begin{array}{l}\text { - Symptoms } \\
\text { - HRQoL PROs }\end{array}$ \\
\hline
\end{tabular}

The granulomatous inflammation of sarcoidosis can be measured by various methods (left box). The endpoint of granulomatous inflammation would be appropriate to detect the anti-sarcoidosis activity of a drug. However, granulomatous inflammation from sarcoidosis may not result in physiologic impairment (middle box). When physiologic impairment occurs, it may be mild and not lead to the development of symptoms. Therefore, the presence of active sarcoidosis (left box) or physiologic impairment (middle box) may be inadequate clinical endpoints to base decisions on whether sarcoidosis patients require therapy. If physiologic impairment leads to significant functional impairment and/or worsening quality of life (right box), then therapy for sarcoidosis is required. Therefore, a rational clinical endpoint would need to incorporate the patient's functional status and health related quality of life.

Abbreviations: ACE, angiotensin converting enzyme; BAL, bronchoalveolar lavage; EF, ejection fraction; HRQoL, health-related quality of life; MRI, magnetic resonance imaging; PET, positron emission tomography; PFT, pulmonary function test; PRO, patient reported outcome measure. Adapted from [80].

\section{Abbreviations}

$\mathrm{CTD}$, connective tissue disease; FVC, forced vital capacity; SAA, serum amyloid A; TNF- $\alpha$, tumor necrosis factor alpha; WASOG, World Association of Sarcoidosis and Other Granulomatous Disorders.

\section{Disclosures}

Marc A. Judson is a consultant for Janssen, Celgene, Novartis, Mitsubishi-Tanabe, and Questcor.

\section{Acknowledgements}

Marc A. Judson wishes to acknowledge Sooyeon Kwon, $\mathrm{PhD}$, for her outstanding assistance formatting the table and figures in this manuscript.

\section{References}

I. Sharma OP: Sarcoidosis around the world. Clin Chest Med 2008, 29:357-63, vii.

2. Baughman RP, Culver DA, Judson MA: A concise review of pulmonary sarcoidosis. Am J Respir Crit Care Med 2011, 183:573-8I.

3. Mukhopadhyay S, Wilcox BE, Myers JL, Bryant SC, Buckwalter SP, Wengenack NL, Yi ES, Aughenbaugh GL, Specks U, Aubry M: Pulmonary necrotizing granulomas of unknown cause: clinical and pathologic analysis of 131 patients with completely resected nodules. Chest 2013, 144:813-24.

\section{FlOOOPrime
RECOMMENDED}

4. Newman LS, Kreiss K, King TE, Seay S, Campbell PA: Pathologic and immunologic alterations in early stages of beryllium disease. Re-examination of disease definition and natural history. Am Rev Respir Dis 1989, 139:1479-86.
5. Mukhopadhyay S, Gal AA: Granulomatous lung disease: an approach to the differential diagnosis. Arch Pathol Lab Med 2010, 134:667-90.

6. Harris $\mathrm{KM}$, McConnochie $\mathrm{K}$, Adams $\mathrm{H}$ : The computed tomographic appearances in chronic berylliosis. Clin Radiol 1993, 47:26-3I.

7. Müller-Quernheim J, Gaede KI, Fireman E, Zissel G: Diagnoses of chronic beryllium disease within cohorts of sarcoidosis patients. Eur Respir J 2006, 27:1190-5.

\section{FlOOOPrime}

\section{RECOMMENDED}

8. Lee N, Barber L, Kanchwala A, Childs, Carter J H, Kataria YP, Judson MA, Mazer MA, Arce S: Low levels of NF-kB/p65 mark anergic CD4+ $T$ cells and correlate with disease severity in sarcoidosis. Clin Vaccine Immunol 20II, I 8:223-34.

9. Marchell RM, Judson MA: Cutaneous sarcoidosis. Semin Respir Crit Care Med 2010, 31:442-51.

10. Drent M, Lower EE, Vries J de: Sarcoidosis-associated fatigue. Eur Respir J 2012, 40:255-63.

II. Hoitsma E, Drent M, Verstraete E, Faber CG, Troost J, Spaans F, Reulen, J P H: Abnormal warm and cold sensation thresholds suggestive of small-fibre neuropathy in sarcoidosis. Clin Neurophysiol 2003, I I 4:2326-33.

\section{FlOOOPrime \\ RECOMMENDED}

12. Bakkers M, Merkies, I S J, Lauria G, Devigili G, Penza P, Lombardi R, Hermans, M C E, van Nes, S I, Baets M de, Faber CG: Intraepidermal nerve fiber density and its application in sarcoidosis. Neurology 2009, 73: | | 142-8.

FIOOOPRime
RECOMMENDED

13. Padilla ML, Schilero GJ, Teirstein AS: Sarcoidosis and transplantation. Sarcoidosis Vasc Diffuse Lung Dis 1997, 14:16-22.

14. Sartin JS, Walker RC: Granulomatous hepatitis: a retrospective review of 88 cases at the Mayo Clinic. Mayo Clin Proc 1991, 66:914-8. 
15. Judson MA, Baughman RP, Teirstein AS, Terrin ML, Yeager H: Defining organ involvement in sarcoidosis: the ACCESS proposed instrument. ACCESS Research Group. A Case Control Etiologic Study of Sarcoidosis. Sarcoidosis Vasc Diffuse Lung Dis 1999, 16:75-86.

\section{FlOOOPrime} RECOMMENDED

16. Judson MA, Costabel U, Drent M, Wells A, Maier L, Koth L, Shigemitsu H, Culver DA, Gelfand J, Valeyre D, Sweiss N, Crouser E, Morgenthau AS, Lower EE, Azuma A, Ishihara M, Morimoto S, Tetsuo Yamaguchi T, Shijubo N, Grutters JC, Rosenbach M, Li H, Rottoli P, Inoue Y, Prasse A, Baughman RP, Organ Assessment Instrument Investigators, The Wasog Sarcoidosis: The WASOG Sarcoidosis Organ Assessment Instrument: An update of a previous clinical tool. Sarcoidosis Vasc Diffuse Lung Dis 2014, 31 : 19-27.

17. Judson MA, Baughman RP: How many organs need to be involved to diagnose sarcoidosis?: An unanswered question that, hopefully, will become irrelevant. Sarcoidosis Vasc Diffuse Lung Dis 2014, 31:6-7.

18. Criado E, Sánchez M, Ramírez J, Arguis P, de Caralt, Teresa M, Perea RJ, Xaubet A: Pulmonary sarcoidosis: typical and atypical manifestations at high-resolution CT with pathologic correlation. Radiographics 2010, 30:1567-86.

19. Baughman RP, Teirstein AS, Judson MA, Rossman MD, Yeager $H$, Bresnitz EA, DePalo L, Hunninghake G, lannuzzi MC, Johns CJ, McLennan G, Moller DR, Newman LS, Rabin DL, Rose C, Rybicki B, Weinberger SE, Terrin ML, Knatterud GL, Cherniak R: Clinical characteristics of patients in a case control study of sarcoidosis. Am J Respir Crit Care Med 2001, 164: 1885-9.

20. Judson MA, Shapiro L, Freitas S, Polychronopoulos VS, Highland KB: Concomitant sarcoidosis and a connective tissue disease: review of the clinical findings and postulations concerning their association. Respir Med 2013, 107:1453-9.

21. Chen ES, Song Z, Willett MH, Heine S, Yung RC, Liu MC, Groshong SD, Zhang Y, Tuder RM, Moller DR: Serum amyloid A regulates granulomatous inflammation in sarcoidosis through Toll-like receptor-2. Am J Respir Crit Care Med 2010, 181:360-73.

\section{FlOOOPrime}

\section{RECOMMENDED}

22. Sfriso P, Caso F, Tognon S, Galozzi P, Gava A, Punzi L: Blau syndrome, clinical and genetic aspects. Autoimmun Rev 2012, 12:44-51.

23. Brinker $\mathrm{H}$ : Granulomatous lesions of unknown significance: the GLUS syndrome. In Sarcoidosis and Other Granulomatous Disorders. Edited by James DG. Philadelphia: W.B. Saunders; 1994, 69-86.

24. Fernández Pérez, Evans R: Granulomatous lymphocytic interstitial lung disease. Immunol Allergy Clin North Am 20I2, 32:62I-32.

25. Yeboah J, Afkhami M, Lee C, Sharma OP: Necrotizing sarcoid granulomatosis. Curr Opin Pulm Med 2012, 18:493-8.

26. Baughman RP, Nagai $S$, Balter M, Costabel U, Drent M, Du Bois R, Grutters JC, Judson MA, Lambiri I, Lower EE, Muller-Quernheim J, Prasse A, Rizzato G, Rottoli P, Spagnolo P, Teirstein A: Defining the clinical outcome status (COS) in sarcoidosis: results of WASOG Task Force. Sarcoidosis Vasc Diffuse Lung Dis 20I I, 28:56-64.

27. Hunninghake GW, Costabel U, Ando M, Baughman R, Cordier JF, Du Bois R, Eklund A, Kitaichi M, Lynch J, Rizzato G, Rose C, Selroos O, Semenzato G, Sharma OP: ATS/ERS/WASOG statement on sarcoidosis. American Thoracic Society/European Respiratory Society/World Association of Sarcoidosis and other Granulomatous Disorders. Sarcoidosis Vasc Diffuse Lung Dis 1999, 16:149-73.

28. Panselinas E, Judson MA: Acute pulmonary exacerbations of sarcoidosis. Chest 2012, 142:827-36.

29. Gottlieb JE, Israel HL, Steiner RM, Triolo J, Patrick H: Outcome in sarcoidosis. The relationship of relapse to corticosteroid therapy. Chest 1997, I I I:623-31.

30. Rizzato G, Montemurro L, Colombo P: The late follow-up of chronic sarcoid patients previously treated with corticosteroids. Sarcoidosis Vasc Diffuse Lung Dis 1998, 15:52-8.

3I. Eule $H$, Weinecke $A$, Roth I, Wuthe $H$ : The possible influence of corticosteroid therapy on the natural course of pulmonary sarcoidosis. Late results of a continuing clinical study. Ann N Y Acad Sci 1986, 465:695-70I.

32. Israel HL, Fouts DW, Beggs RA: A controlled trial of prednisone treatment of sarcoidosis. Am Rev Respir Dis 1973, 107:609-14.

33. Lower EE, Baughman RP: Prolonged use of methotrexate for sarcoidosis. Arch Intern Med 1995, I 55:846-5I.

34. Panselinas E, Rodgers JK, Judson MA: Clinical outcomes in sarcoidosis after cessation of infliximab treatment. Respirology 2009, 14:522-8.

35. Paramothayan NS, Lasserson TJ, Jones PW: Corticosteroids for pulmonary sarcoidosis. Cochrane Database Syst Rev 2005: CD00 I I I4.

36. Zaki MH, Lyons HA, Leilop L, Huang CT: Corticosteroid therapy in sarcoidosis. A five-year, controlled follow-up study. $N$ Y State J Med 1987, 87:496-9.

37. Schutt AC, Bullington WM, Judson MA: Pharmacotherapy for pulmonary sarcoidosis: a Delphi consensus study. Respir Med 2010, 104:717-23.

38. McKinzie BP, Bullington WM, Mazur JE, Judson MA: Efficacy of shortcourse, low-dose corticosteroid therapy for acute pulmonary sarcoidosis exacerbations. Am J Med Sci 2010, 339:1-4.

39. Johns CJ, Michele TM: The clinical management of sarcoidosis. A 50-year experience at the Johns Hopkins Hospital. Medicine (Baltimore) 1999, 78:65-III.

40. Baughman RP, Winget DB, Lower EE: Methotrexate is steroid sparing in acute sarcoidosis: results of a double blind, randomized trial. Sarcoidosis Vasc Diffuse Lung Dis 2000, 17:60-6.

\section{FlOOOPrime}

RECOMMENDED

4I. Doty JD, Mazur JE, Judson MA: Treatment of corticosteroidresistant neurosarcoidosis with a short-course cyclophosphamide regimen. Chest 2003, 124:2023-6.

42. Vorselaars, Adriane D M, Wuyts WA, Vorselaars, Veronique M M, Zanen P, Deneer, Vera H M, Veltkamp M, Thomeer M, van Moorsel, Coline H M, Grutters JC: Methotrexate vs azathioprine in secondline therapy of sarcoidosis. Chest 2013, 144:805-12.

\section{FlOOOPrime \\ RECOMMENDED}

43. Sahoo DH, Bandyopadhyay D, Xu M, Pearson K, Parambil JG, Lazar CA, Chapman JT, Culver DA: Effectiveness and safety of leflunomide for pulmonary and extrapulmonary sarcoidosis. Eur Respir J 2011, 38: I 145-50.

\section{FlOOOPrime
RECOMMENDED}

44. Sharma OP, Vucinić V: Sarcoidosis of the thyroid and kidneys and calcium metabolism. Semin Respir Crit Care Med 2002, 23:579-88.

45. Zic JA, Horowitz DH, Arzubiaga C, King LE: Treatment of cutaneous sarcoidosis with chloroquine. Review of the literature. Arch Dermatol 1991, I27:1034-40.

46. Fries JF, Williams CA, Ramey D, Bloch DA: The relative toxicity of disease-modifying antirheumatic drugs. Arthritis Rheum 1993, 36:297-306.

47. Baughman RP, Lower EE: Infliximab for refractory sarcoidosis. Sarcoidosis Vasc Diffuse Lung Dis 200I, 18:70-4.

48. Doty JD, Mazur JE, Judson MA: Treatment of sarcoidosis with infliximab. Chest 2005, 127:1064-7I.

49. Stagaki E, Mountford WK, Lackland DT, Judson MA: The treatment of lupus pernio: results of 116 treatment courses in 54 patients. Chest 2009, 135:468-76.

50. Sodhi M, Pearson K, White ES, Culver DA: Infliximab therapy rescues cyclophosphamide failure in severe central nervous system sarcoidosis. Respir Med 2009, 103:268-73.

5I. Baughman RP, Drent M, Kavuru M, Judson MA, Costabel U, Du Bois R, Albera C, Brutsche M, Davis G, Donohue JF, Müller-Quernheim J, Schlenker-Herceg R, Flavin S, Lo KH, Oemar B, Barnathan ES: Infliximab 
therapy in patients with chronic sarcoidosis and pulmonary involvement. Am J Respir Crit Care Med 2006, I 74:795-802.

\section{FlOOOPrime
RECOMMENDED}

52. Judson MA, Baughman RP, Costabel U, Flavin S, Lo KH, Kavuru MS, Drent M: Efficacy of infliximab in extrapulmonary sarcoidosis: results from a randomised trial. Eur Respir J 2008, 3 I: | I 89-96.

53. Fehrenbach H, Zissel G, Goldmann T, Tschernig T, Vollmer E, Pabst R, Müller-Quernheim J: Alveolar macrophages are the main source for tumour necrosis factor-alpha in patients with sarcoidosis. Eur Respir J 2003, 2 1:421-8.

\section{FIOOOPrime}

54. Ziegenhagen MW, Rothe ME, Zissel G, Müller-Quernheim J: Exaggerated TNFalpha release of alveolar macrophages in corticosteroid resistant sarcoidosis. Sarcoidosis Vasc Diffuse Lung Dis 2002, 19:185-90.

\section{FlOOPrime}

RECOMMENDED

55. Baughman RP, Lower EE, Bradley DA, Raymond LA, Kaufman A: Etanercept for refractory ocular sarcoidosis: results of a double-blind randomized trial. Chest 2005, I 28: 1062-47.

\section{FlOOPrime}

\section{RECOMMENDED}

56. Pariser RJ, Paul J, Hirano S, Torosky C, Smith M: A double-blind, randomized, placebo-controlled trial of adalimumab in the treatment of cutaneous sarcoidosis. J Am Acad Dermatol 2013, 68:765-73.

\section{FlOOOPrime
RECOMMENDED}

57. Sweiss NJ, Noth I, Mirsaeidi M, Zhang W, Naureckas ET, Hogarth DK, Strek M, Caligiuri P, Machado RF, Niewold TB, Garcia, Joe G N, Pangan AL, Baughman RP: Efficacy Results of a 52-week Trial of Adalimumab in the Treatment of Refractory Sarcoidosis. Sarcoidosis Vasc Diffuse Lung Dis 2014, 3 I:46-54.

\section{FlOOOPrime}

\section{RECOMMENDED}

58. Baughman RP, Nunes H, Sweiss NJ, Lower EE: Established and experimental medical therapy of pulmonary sarcoidosis. Eur Respir J 2013, 41:|424-|438.

59. Louie GH, Chitkara P, Ward MM: Relapse of sarcoidosis upon treatment with etanercept. Ann Rheum Dis 2008, 67:896-8.

\section{FlOOOPrime
RECOMMENDED}

60. van der Stoep, Deborah, Braunstahl G, van Zeben J, Wouters J: Sarcoidosis during anti-tumor necrosis factor-alpha therapy: no relapse after rechallenge. J Rheumatol 2009, 36:2847-8.

6I. Burns AM, Green PJ, Pasternak S: Etanercept-induced cutaneous and pulmonary sarcoid-like granulomas resolving with adalimumab. J Cutan Pathol 2012, 39:289-93.

62. Verschueren K, van Essche E, Verschueren P, Taelman V, Westhovens R: Development of sarcoidosis in etanercept-treated rheumatoid arthritis patients. Clin Rheumatol 2007, 26:1969-71.

\section{FlOOOPrime RECOMMENDED}

63. O'Shea FD, Marras TK, Inman RD: Pulmonary sarcoidosis developing during infliximab therapy. Arthritis Rheum 2006 , 55:978-8I.

\section{FlOOOPrime RECOMMENDED}

64. Mirnezami R, Nicholson J, Darzi A: Preparing for precision medicine. N Engl J Med 2012, 366:489-9I.
65. Mugnier B, Balandraud N, Darque A, Roudier C, Roudier J, Reviron D: Polymorphism at position -308 of the tumor necrosis factor alpha gene influences outcome of infliximab therapy in rheumatoid arthritis. Arthritis Rheum 2003, 48:1849-52.

\section{FlOOOPrime
RECOMMENDED}

66. Zeng Z, Duan Z, Zhang T, Wang S, Li G, Gao J, Ye D, Xu S, Xu J, Zhang L, Pan F: Association between tumor necrosis factor- $\alpha$ (TNF- $\alpha$ ) promoter -308 G/A and response to TNF- $\alpha$ blockers in rheumatoid arthritis: a meta-analysis. Mod Rheumatol 2013, 23:489-95

\section{FlOOOPrime}

\section{RECOMMENDED}

67. Wijnen PA, Cremers JP, Nelemans PJ, Erckens RJ, Hoitsma E, Jansen TL, Bekers O, Drent M: Association of the TNF- $\alpha$ G-308A polymorphism with TNF-inhibitor response in sarcoidosis. Eur Respir J 2014, 43:1730-9.

\section{FIOOOPRime
RECOMMENDED}

68. Kataria YP, Holter JF: Immunology of sarcoidosis. Clin Chest Med 1997, 18:719-39.

69. Belkhou A, Younsi R, El Bouchti I, El Hassani S: Rituximab as a treatment alternative in sarcoidosis. Joint Bone Spine 2008, 75:5II-2.

70. Dasilva V, Breuil V, Chevallier P, Euller-Ziegler L: Relapse of severe sarcoidosis with an uncommon peritoneal location after TNFalpha blockade. Efficacy of rituximab, report of a single case. Joint Bone Spine 2010, 77:82-3

7I. Bomprezzi R, Pati S, Chansakul C, Vollmer T: A case of neurosarcoidosis successfully treated with rituximab. Neurology 2010 , 75:568-70.

72. Sweiss NJ, Lower EE, Mirsaeidi M, Dudek S, Garcia, Joe G N Perkins D, Finn PW, Baughman RP: Rituximab in the treatment of refractory pulmonary sarcoidosis. Eur Respir J 2014, 43:1525-8.

73. Mostard, Rémy L M, Verschakelen JA, van Kroonenburgh, Marinus J P G, Nelemans PJ, Wijnen, Petal A H M, Vöö S, Drent M: Severity of pulmonary involvement and (I8)F-FDG PET activity in sarcoidosis. Respir Med 2013, 107:439-47.

\section{FlOOOPrime}

\section{RECOMMENDED}

74. Beegle SH, Barba K, Gobunsuy R, Judson MA: Current and emerging pharmacological treatments for sarcoidosis: a review. Drug Des Devel Ther 2013, 7:325-38.

75. Judson MA, Baughman RP, Costabel U, Mack M, Barnathan ES: The potential additional benefit of infliximab in patients with chronic pulmonary sarcoidosis already receiving corticosteroids: a retrospective analysis from a randomized clinical trial. Respir Med 2014, 108:189-94.

76. Judson MA, Boan AD, Lackland DT: The clinical course of sarcoidosis: presentation, diagnosis, and treatment in a large white and black cohort in the United States. Sarcoidosis Vasc Diffuse Lung Dis 2012, 29:119-27.

77. Cox CE, Donohue JF, Brown CD, Kataria YP, Judson MA: The Sarcoidosis Health Questionnaire: a new measure of healthrelated quality of life. Am J Respir Crit Care Med 2003, I 68:323-9.

78. Cox CE, Donohue JF, Brown CD, Kataria YP, Judson MA: Healthrelated quality of life of persons with sarcoidosis. Chest 2004 1 25:997-1004.

79. Baughman RP, Drent $M$, Culver DA, Grutters IC, Handa $T$, Humbert M, Judson MA, Lower EE, Mana J, Pereira CA, Prasse A, Sulica R, Valyere D, Vucinic V, Wells AU: Endpoints for clinical trials of sarcoidosis. Sarcoidosis Vasc Diffuse Lung Dis 2012, 29:90-8.

80. Judson MA: The treatment of pulmonary sarcoidosis. Respir Med 2012, 106: $|35|-6 \mid$ 